\title{
New Polymer Composites Including a Phenol-Formaldehyde Resin Binder Designed for Self-Lubricating Sliding Pair Elements
}

\author{
Sylwester Stawarz ${ }^{1 *}$, Magdalena Stawarz' ${ }^{1}$ Wojciech Kucharczyk' \\ Wojciech Żurowski ${ }^{1}$, Agnieszka Różycka ${ }^{1}$
}

1 Kazimierz Pulaski University of Technology and Humanities in Radom, Faculty of Mechanical Engineering, ul. Stasieckiego 54B, 26-600 Radom, Poland

* Corresponding author's e-mail: stawarz@uthrad.pl

\begin{abstract}
The paper presents the test results of composites used in self-lubricating sliding pairs where resol phenol-formaldehyde (AW-1, FDP), novolak phenol-formaldehyde, and anthracene-phenol resins were applied as binders. Thermal resistance, load capacity, friction resistances, wear values, and formation of top layers of friction-coupled elements were studied. A model composite with $9 \mathrm{MPa} \times \mathrm{m} / \mathrm{s}$ load capacity and friction wear resistance greater than of the composites available in the domestic and international markets, comparable friction resistances, and lower production costs was developed.
\end{abstract}

Keywords: quality improvement, means of transport, composites, self-lubricating sliding pairs.

\section{INTRODUCTION}

The dynamic development of the motor technology, among others, showed that lubrication in its classic sense (plain bearings) is not recommended or even impossible, particularly at high and low temperatures.

Elimination of lubricants greatly improves the design and cuts the operating costs, for instance, improved operating conditions of a piston group help to reduce the fuel consumption and environment pollution (Posmyk, 2013; Wieleba et al., 2016).

In sliding pairs, especially those using even very poor lubricants, plastic wears far more than its metal counterpart. The wear mechanism and intensity of plastics are also highly dependent on the temperature, a function of pressures, sliding velocities, and friction coefficients in a given friction center (Wieleba, 2013). At lower velocities, the wear intensity of plastics in friction is more dependent on pressure than on velocity, whereas the dependence is reversed at greater velocities. In practice, this means that the fillers mitigating friction and wear processes should be used in material compositions and the materials should be tested on friction and wear stands that provide for maximum approximation to the operating conditions of real friction pairs.

The materials displaying low friction resistances when operating with metals (PTFE, graphite, $\mathrm{BN}, \mathrm{MoS}_{2}$, and the like) cannot be employed in their pure forms, chiefly due to their low cohesive strength (low shear strength) (Wieleba, 2002). The attempts at reinforcing them with granular (metal, mineral, and organic) and fibrous (including organic and ceramic) fillers have improved their cohesion, yet also raised their friction resistances by several to a dozen per cent, which exacerbates the thermal conditions in the friction spaces and reduces the resistance to the friction wear and load capacity. The attempts at reinforcing composites with the matrices of thermo- and chemo-setting or thermoplastic polymers (Choromański and Kowara, 2013) have improved the load capacity and resistance to friction wear, although the load capacities of such composites continue to be limited to $\mathrm{p} \times \mathrm{v} \leq 6 \mathrm{MPa} \times \mathrm{m} / \mathrm{s}$. 
Additionally, the production costs (energy consumption) of the composites are relatively high (Adam, 1999).

Our review of literature indicated a few studies on the application of thermo-setting resins, e.g. phenol-formaldehyde resins, to such composites, successfully used in frictional composites that operate under extremely difficult conditions (Frost and Sullivan, 2002; Mindur, 2004; Stryczek, 2015; Mindur, 2008; Capanidis et al., 2014).

\section{DESIGN OF EXPERIMENTAL TESTING}

A thermo-setting resin reinforced with a fibrous filler and high-slip substances, namely, PTFE including a solid lubricant (graphite) addition, was adopted as a matrix (support) for our solution.

Specialist literature fails to offer any unambiguous methods of producing the desirable tribological characteristics of composites as early as the stage of developing composition. There are no methods of choosing an optimum matrix of ingredients and fillers, reasonable selection of types and proportions of composite ingredients. This requires persistent and arduous experimentation to select composite ingredients in order to arrive at the desirable friction and wear characteristics.
Thus, only a final tribological experiment with a finished sliding composite allows determining the real tribological characteristics.

Considering certain specific physicochemical properties, e.g. type of friction electrification, technological and performance characteristics, e.g. processability, production costs or component availability, and based on the authors' preliminary testing (Sierpacka et al., 2004), resol phenol-formaldehyde (AW-1, FDP), novolak phenol-formaldehyde, and anthracene-phenol resins were applied as binders, while the types and quantities of the modifiers were selected for the purposes of analysis. Linters cotton fiber served as the filler.

The design of experimental testing and methods of composite production are illustrated in Figure 1.

Since major ingredients of the experimental composite varieties (Table 1) came as solid powders (novolak phenols and anthracene- phenol tarflen suspensions), fibers (Linters), and liquids (AW1, FDP resins, PTFE water dispersions), versions I and II of the test samples were produced.

It was assumed that the mechanical and thermal load capacities and wear resistance of such a composite can be increased while maintaining the friction resistances at the existing levels.

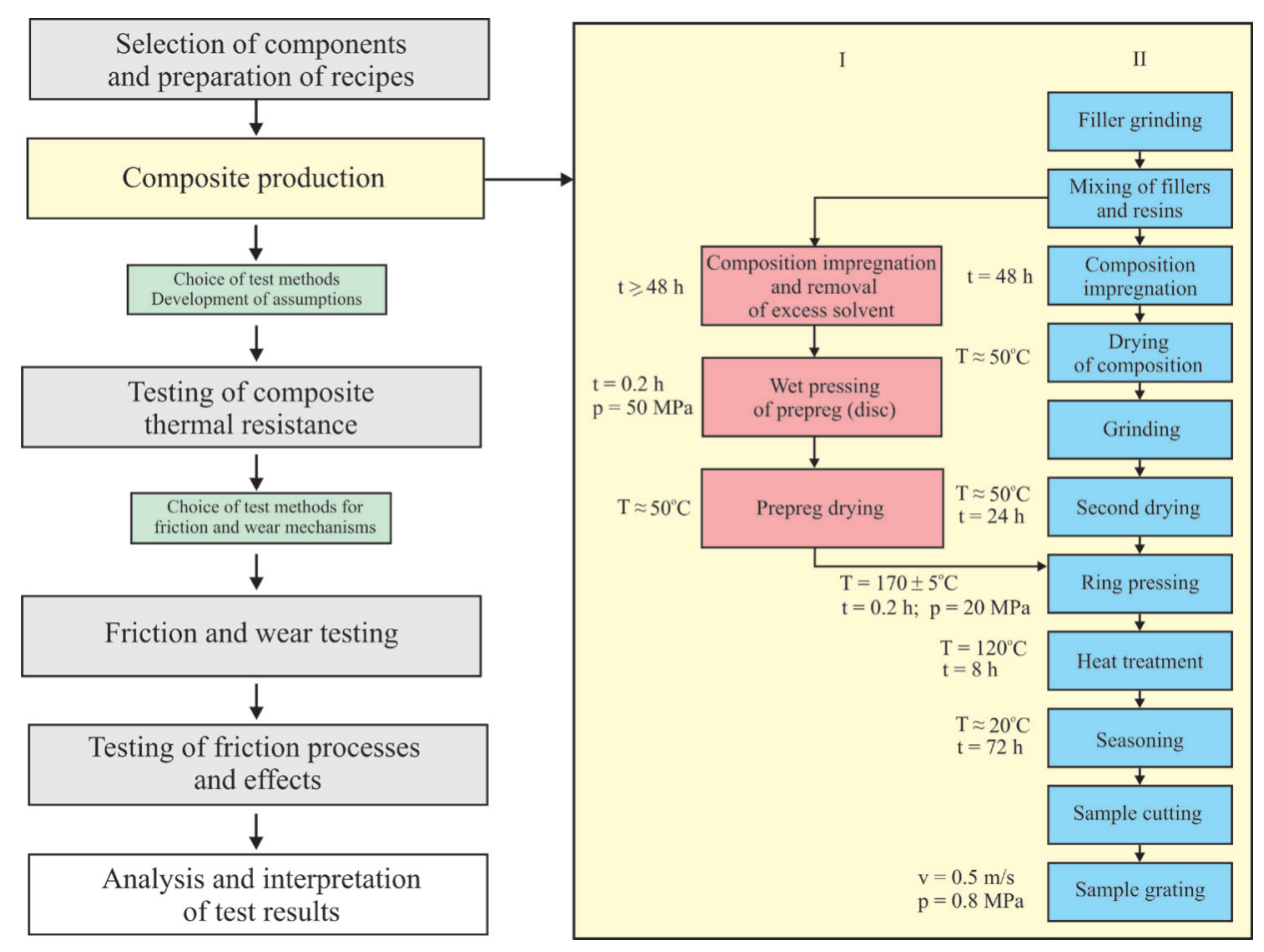

Fig. 1. Design of experiments, production of the composite samples 
Table 1. Composite ingredients

\begin{tabular}{|c|c|c|c|c|c|c|}
\hline \multirow{2}{*}{\multicolumn{2}{|c|}{ Ingredient }} & \multicolumn{5}{|c|}{ Composite contents, (weight \%) } \\
\hline & & K1 & K2 & $\mathrm{K} 3$ & K4 & $\mathrm{KO}$ \\
\hline 1 & Phenol-formaldehyde resin AW 1 & 25 & - & - & - & \multirow{8}{*}{$\begin{array}{l}\text { Production } \\
\text { reference } \\
\text { composite } \\
\text { 85PTFE }+15 \% \\
\text { graphite }\end{array}$} \\
\hline 2 & Phenol-formaldehyde resin FDP & - & - & - & 25 & \\
\hline 3 & Novolak resin & - & 25 & - & - & \\
\hline 4 & Anthracene resin & - & - & 25 & - & \\
\hline 5 & Linters cotton fibres & 20 & 20 & 20 & 20 & \\
\hline 6 & PTFE - water emulsion & 44 & 44 & 44 & 44 & \\
\hline 7 & Graphite & 10 & 10 & 10 & 10 & \\
\hline 8 & Silicone oil & 1 & 1 & 1 & 1 & \\
\hline
\end{tabular}

\section{TESTING OF THERMAL RESISTANCE}

Since composites can be employed as part of the friction pairs operating under high loads and heightened temperatures, the thermal degradation of the composite was tested.

The choice, mounting, and lubrication of a bearing are the basic conditions affecting its correct and long-term operation without seizure. The temperatures of properly mounted and lubricated bearings should not excess $70^{\circ} \mathrm{C}$ and stabilise at a lower level during operation (Wierzcholski, 2015).

Differential thermal analysis supplies much information about the behaviour of polymers, plastics containing foreign ingredients, and polymer mixtures. A T-3427 type derivatograph was used for the analysis. The degradation processes of the composite structure under the impact of temperature correspond to the endothermal effects on the DTA curve. The oxidation process is recorded as an exothermal effect.

These parameters were determined on the basis of TG (mass change) and auxiliary DTG (mass change derivative) curves. The temperature at which the TG curve begins its inflection is assumed to be the thermal stability temperature. Mass loss is treated as the characteristic quantity of the polymer degradation process. The initial mass change observed by means of the derivatograph method that takes place at the initial degradation temperature $\left(T_{p}\right)$ proves the thermal resistance of the material; therefore, this temperature was adopted as the parameter defining thermal resistance of the composite. The temperature up to which mass is not lost (temperature of thermal stability $T_{s t},{ }^{\circ} \mathrm{C}$ ) was treated as the thermal resistance boundary.

Testing of thermal resistance demonstrated a maximum resistance of AW1 phenol-formaldehyde resin (K1 - Figure 2) and FDP phenol-formaldehyde resin (K4). A lower resistance was noted for the composite including an anthracene (K2) Novolak phenol-formaldehyde (K3) matrix. The composites based on the anthracene resin exhibited a minimum thermal resistance; therefore, they are not recommended for high temperature applications. The analysis of the test results pointed to the beneficial effects of phenol-formaldehyde resin matrix. The results are presented in Table 2.

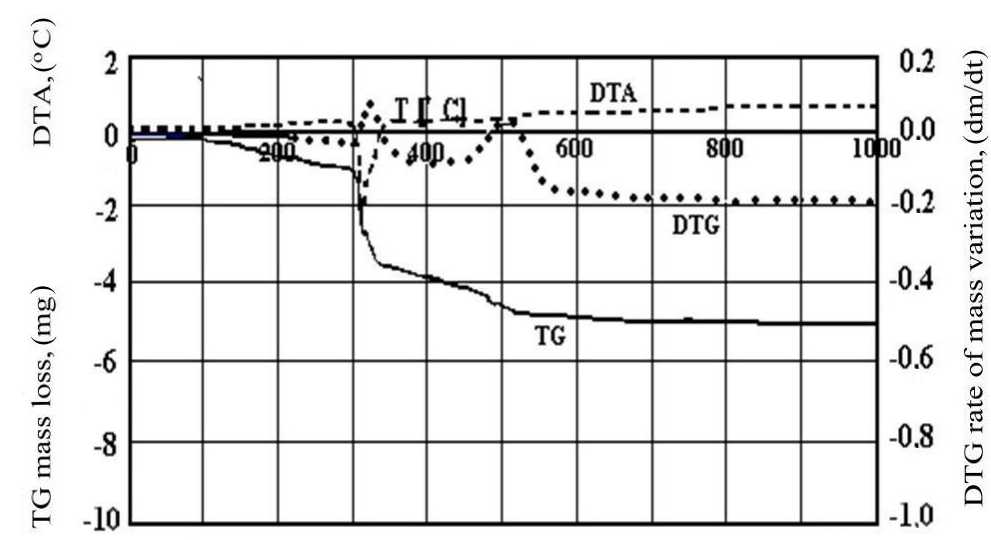

Fig. 2. Derivatogram of the composite based on AW1 phenol-formaldehyde resin 
Table 2. Results of derivatographic testing of composite thermal degradation

\begin{tabular}{|c|c|c|c|}
\hline $\begin{array}{c}\text { Sample } \\
\text { name }\end{array}$ & $\begin{array}{c}\text { Thermal } \\
\text { resistance, } \\
T_{p}\left({ }^{\circ} \mathrm{C}\right)\end{array}$ & $\begin{array}{c}\text { End of } \\
\text { degradation } \\
\text { temperature, } T_{k} \\
\left({ }^{\circ} \mathrm{C}\right)\end{array}$ & $\begin{array}{c}\text { Mass loss, } \\
\Delta \mathrm{m}(\%)\end{array}$ \\
\hline $\mathrm{K} 1$ & 280 & 1000 & 23 \\
\hline $\mathrm{K} 2$ & 230 & 550 & 40 \\
\hline $\mathrm{K} 3$ & 220 & 600 & 38 \\
\hline $\mathrm{K} 4$ & 270 & 920 & 32 \\
\hline
\end{tabular}

\section{TRIBOLOGICAL TESTING}

Following the thermal resistance assessment, the composites with AW1 and FDP phenol-formaldehyde resin matrices were selected for tribological testing.

The tribological properties (friction coefficient and temperature, wear properties) were evaluated in a pair containing 49HRC steel using T-05 tester at the following friction parameters::

- Pressure range of $1.25 \div 10 \mathrm{MPa}$;

- Velocity of $0.5 \mathrm{~m} / \mathrm{s}$;

- Technically dry friction.

A satisfactory evaluation with no decohesion in the friction process under a load $p \cdot v \geq 6 \mathrm{MPa} \cdot \mathrm{m} / \mathrm{s}$ along the path $s=10^{4} \mathrm{~m}$ and friction temperature below $120^{\circ} \mathrm{C}, 2 \mathrm{~mm}$ deep from the surface was adopted as the criterion of the composite's mechanical and thermal properties.

The tested composites attained the assumed loading capacities: production composite $\mathrm{KO} \sim 6.2 \mathrm{MPa} \times \mathrm{m} / \mathrm{s}$, composite $\mathrm{K} 4 \sim 7.5 \mathrm{MPa} \times \mathrm{m} / \mathrm{s}$, and composite $\mathrm{K} 1>9 \mathrm{MPa} \times \mathrm{m} / \mathrm{s}$ - Figure 3 .

Further testing proved that the $\mathrm{K} 1$ composite (AW1 resinmatrix), comparing to the $\mathrm{K} 4$ composite (FDP resin matrix), displayed a higher friction coefficient, especially under greater pressures $\left(\mu_{\text {śr }}=0.072\right.$ and 0.07 , respectively) and similar wear intensity $\left(Z=32\right.$ and $\left.27 \mu \mathrm{m} / 10^{3} \mathrm{~m}\right)$. The $\mathrm{KO}$ production composite was subject to decohesion at a pressure of approx. $6 \mathrm{MPa}-$ Figure 4 .

The wear intensity was determined in weight and linear terms by means of T-05. Weight was converted to linear wear. Average wear intensities expressed in $\mu \mathrm{m} / 10^{3} \mathrm{~m}$ are illustrated in Figure 5, which shows an averaged value of a full test cycle along the path of $\sim 4 \times 10^{4} \mathrm{~m}$ under a pressure above $1.25 \div 10 \mathrm{MPa}$.

The wear mechanism of the composite including a phenol-formaldehyde resin matrix is essentially different from that of the production composite. The former is chiefly worn by removing the cotton fibers impregnated with resin and PTFE (Figure 6a), with finer wear products in the case of AW1 resin matrix (Figure 6b). As far as the reference composite is concerned, the wear occurs by slicing and shearing of the filler (the wear products are of irregular and flake shapes) Figure 6c. In addition, the plastic flow of the production composite and absence of flow traces for the composites including the phenol-formaldehyde resin matrix were observed.

Roughness of the friction surfaces of the K1 and K4 composite pair elements, of the optimum tribological properties among the tested composites, and of the production composite, were measured.

The friction surface roughness of both the composite and its metal partner was minimum for the K1 composite (including AW1 phenol-formaldehyde resin matrix) - Figure 7. As the surface roughness of composite BS 11 is lower than that of the K4 composite, the share of the molecular component in friction resistances can be expected to be greater with regard to AW1 resin matrix composite than for the FDP resin matrix composite.

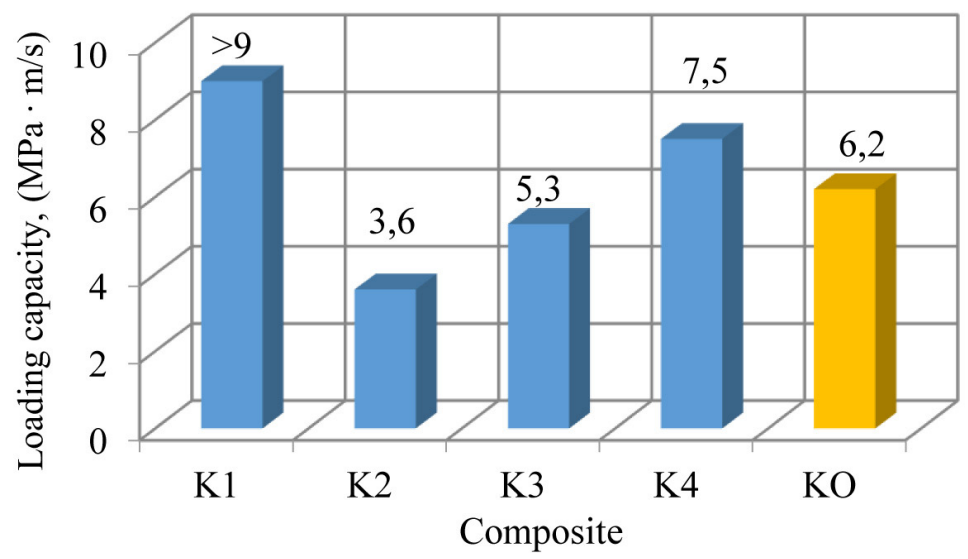

Fig. 3. Decohesion loading capacities and excesses of $120^{\circ} \mathrm{C}$ in testing with T-05 tester 


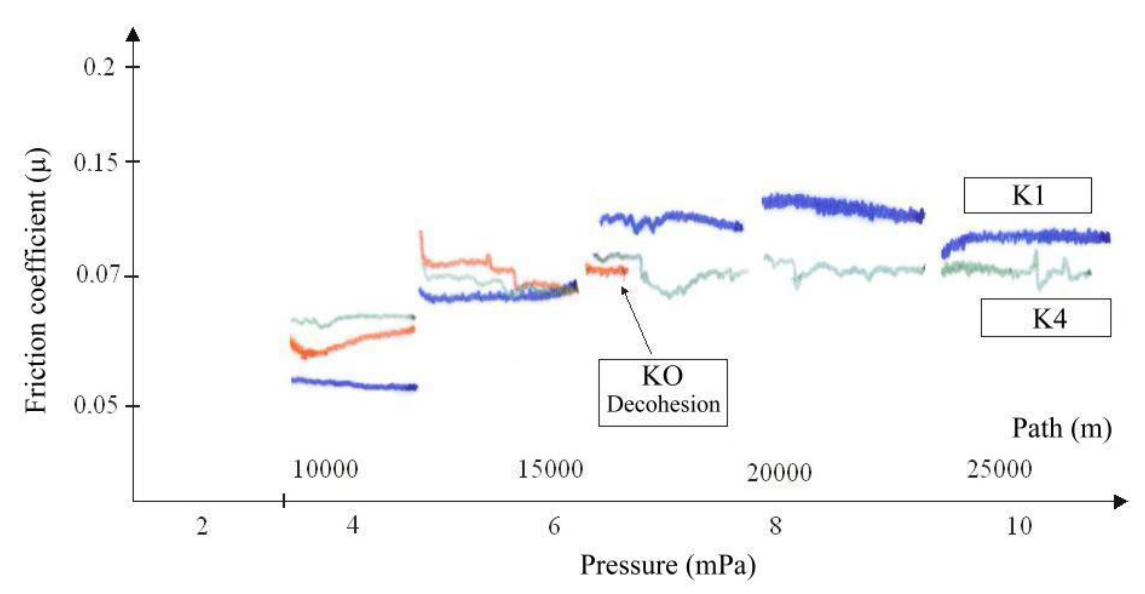

Fig. 4. Friction coefficient and temperature and wear intensity dependent on pressure $(v=0.5 \mathrm{~m} / \mathrm{s})$ as produced by $\mathrm{T}-05$ tester

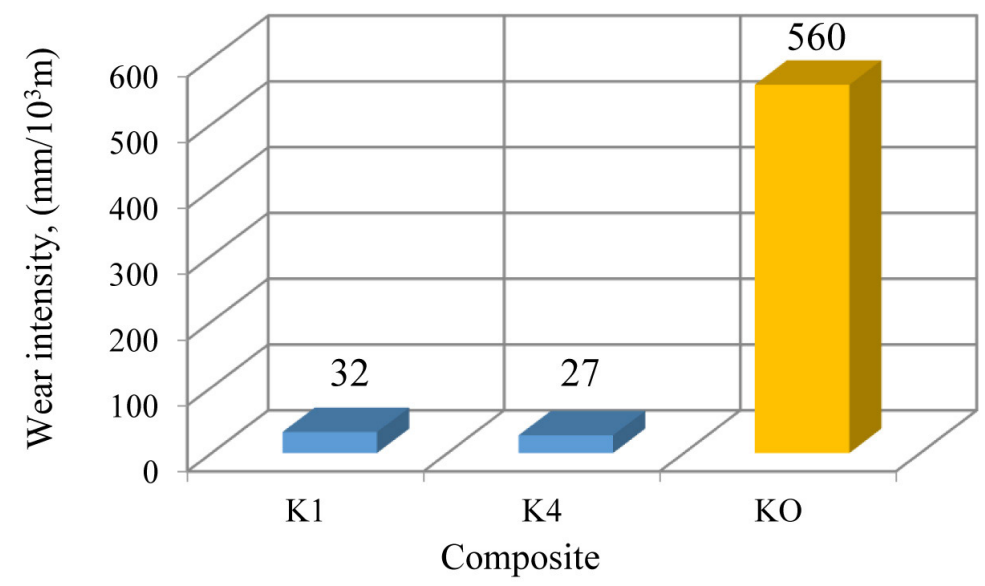

Fig. 5. Average intensity of composite wear following a full testing programme with T-05 tester

a)
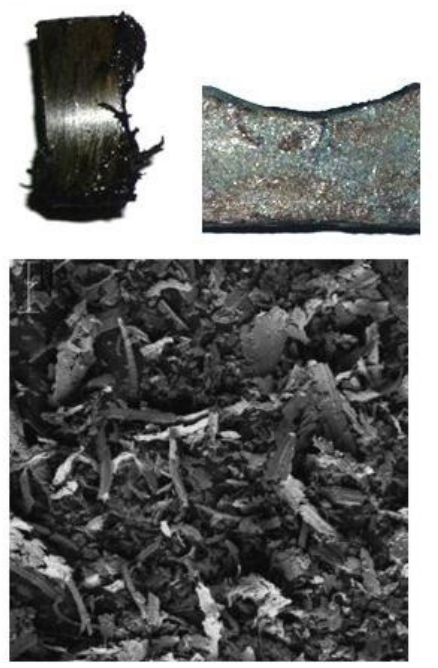

b)
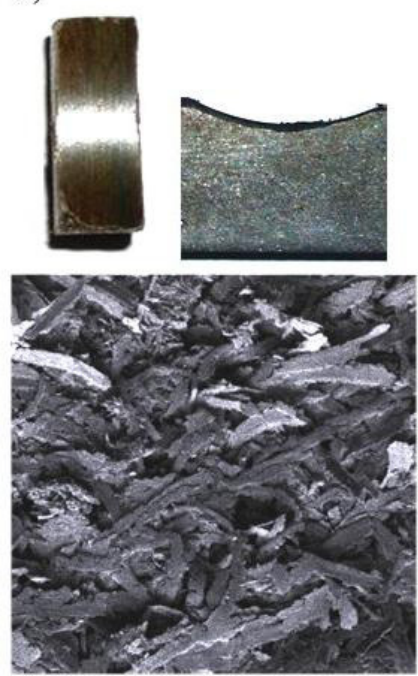

c)
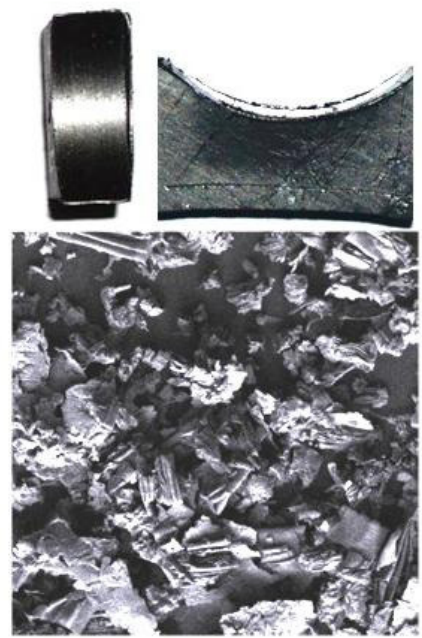

Fig. 6. Observation of macrosamples, friction micro-surfaces, wear products, and SEM microstructures for wear traces following tribological tests of the composites:

$\mathrm{K} 4$ (a), K1 (b) and KO (c) using T-05 tester, under a pressure of $10 \mathrm{MPa}$ 


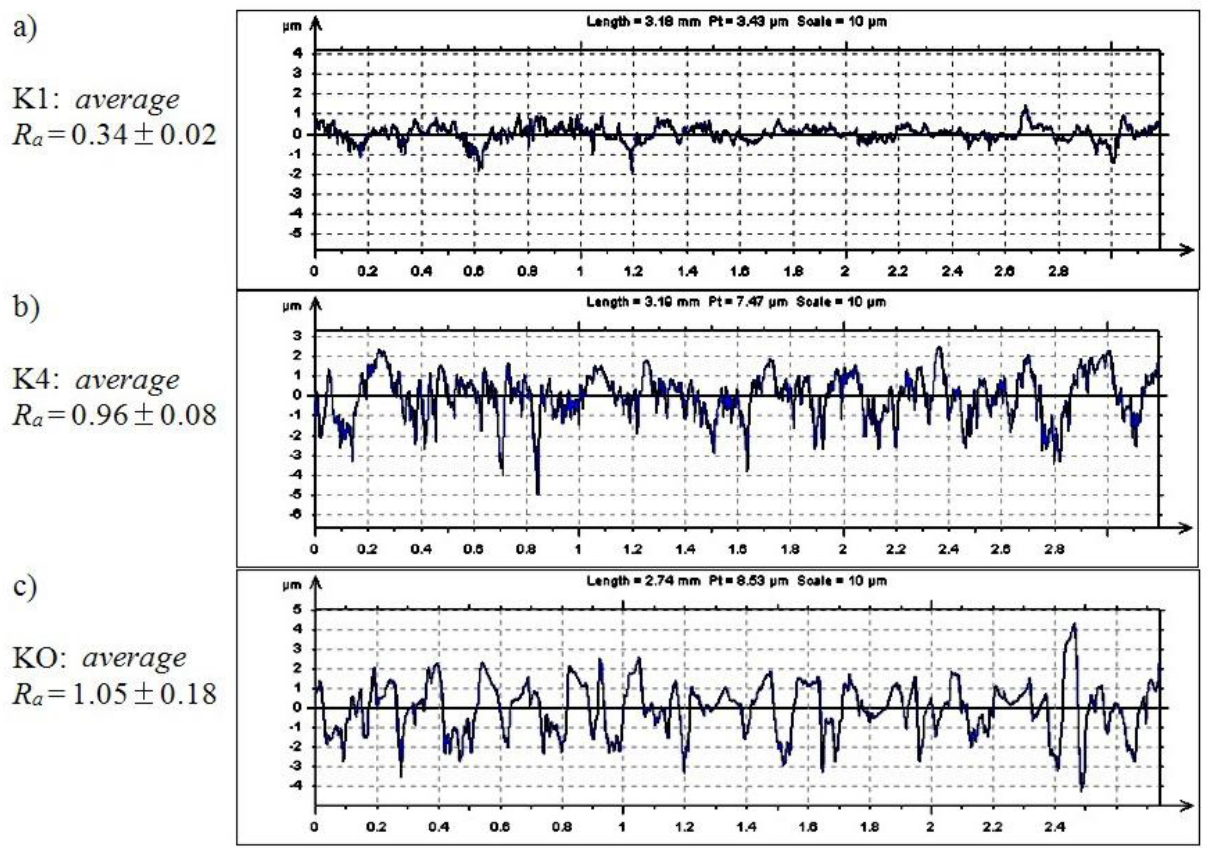

Fig. 7. Microgeometry of friction surfaces of samples working with a steel countersample (tester's roller) following the tribological test

\section{RESULTS AND DISCUSSION}

a) Thermal stability of the composites is in the temperature range of $220-280^{\circ} \mathrm{C}$.

b) Total mass loss on thermal degradation of the composite (up to $1000^{\circ} \mathrm{C}$ ) is within $18-42 \%$, with approx. $53 \%$ for the FDP resin only.

c) The assumed loading capacity of $\geq 6 \mathrm{MPa} \times \mathrm{m} / \mathrm{s}$ was only attained by three composites tested: the KO production composite reached $\sim 6.2 \mathrm{MPa} \times \mathrm{m} / \mathrm{s}$, the K4 FDP phenol-formaldehyde resin matrix composite $\sim 7.5 \mathrm{MPa} \times \mathrm{m} / \mathrm{s}$. The loading capacity of AW1 phenol-formaldehyde composite was maximum, above 9 $\mathrm{MPa} \times \mathrm{m} / \mathrm{s}$;

d) The assumed friction coefficient $(0.1 \pm 0.05)$ was achieved by both phenol-formaldehyde resin matrix composites (under a pressure $>6.25 \mathrm{MPa}$ ). The friction coefficients of the tested and production composites were comparable for pressures $<6 \mathrm{MPa}$.

e) Wear in the entire programmed test cycle was somewhat lower for the K1AW1 phenol-formaldehyde composite, slightly higher for the K4 FDP resin matrix composite, and multiple times greater for the production (reference, $\mathrm{KO})$ composite.

\section{CONCLUSIONS}

With regard to all the evaluation indicators: thermal resistance, loading capacity, friction resistances, wear, and surface layer formation of friction paired elements, the resol phenol-formaldehyde resin matrix composites (AW1 and FDP) produced the best results.

1. The better results of the resol phenol (liquid) resins when compared to the novolak (solid) presentations are likely to arise from an improved wettability of filler particles with a liquid matrix as a composition is prepared for pressing - Figure 1 .

2. The slightly poorer results for the FDP resin matrix composites than for the AW1 resin matrix composites are likely to stem from a better dispersion of the PTFE particles across the matrix (PTFE and AW1 resin particles were suspensions and water solutions, respectively, in the process of homogenisation).

3. The wear mechanisms were found to vary for the different matrices, as demonstrated not only by surface roughness, but also the analysis of friction wear products.

4. A composite model was generated with an enhanced loading capacity of $9 \mathrm{MPa} \times \mathrm{m} / \mathrm{s}$ and resistance to friction wear that is significantly 
greater than of domestic and international composites available in the market, comparable friction resistances and lower production costs.

\section{REFERENCES}

1. Adam A., Grunthaler K. H. Self-lubricating bearing material and friction bearing made of such a materials. TriboTest Journal, 3, 1999.

2. Capanidis D., Wieleba W., Kowalewski P. Effect of certain lubricative exploational preparations on the tribological properties of selected PTFE composites during friction with steel. 20th International Symposium on Surfactants in Solution. SIS, 533, 2014.

3. Choromański W., Kowara J. Personal rapid transit vehicle with polyurethane wheels - modelling and simulation issues. The Archives Of Transport, 3-4, 2013, 71-79.

4. Frost \& Sullivan. Analysis of the European commercial vehicle telematics market. Frost \& Sullivan Report, B042, 2002.

5. Mindur L. Współczesne technologie transportowe. Radom, Wydawnictwo Politechniki Radomskiej, 2004.

6. Mindur L. Technologie transportowe XXI w. Ra- dom: Wydawnictwo Instytutu Technologii Eksploatacji, 2008.

7. Posmyk A. Wpływ nowych technologii i materiałów na poprawę jakości transportu. Zeszyty Naukowe Politechniki Śląskiej, Transport, 1882/78, 2013, 109-115.

8. Sierpacka B., Szumniak J., Stawarz S. Load-carrying ability of polymeric composite designed for sliding bearings working on dry friction. Tribologia, 4, 2004, 195-202.

9. Stryczek J. Modelowe elementy hydrauliczne $\mathrm{z}$ tworzyw sztucznych. Hydraulika i Pneumatyka, 35/2, 2015, 5-8.

10. Wieleba W., Leśniewski T., Elemes D. A. Friction processes of selected polymers sliding on steel and duralumin in a lubricant environment. Tribologia, 4, 2016, 201-210.

11. Wieleba W. Analiza procesów tribologicznych zachodzących podczas współpracy kompozytów PTFE ze stalą. Wrocław: Wydawnictwo Politechniki Wrocławskiej, 2002.

12. Wieleba W. Bezobsługowe łożyska ślizgowe z polimerów termoplastycznych. Wrocław: Wydawnictwo Politechniki Wrocławskiej, 2013.

13. Wierzcholski K. Probabilistic studies for (slide\&rolling) bearing seizure determination. Tribologia, 4, 2015, 199-206. 